Review

\title{
Neuroprotective Effect of SGLT2 Inhibitors
}

\author{
Agnieszka Pawlos (), Marlena Broncel *, Ewelina Woźniak (1) and Paulina Gorzelak-Pabiś $\mathbb{C}$
}

check for updates

Citation: Pawlos, A.; Broncel, M.;

Woźniak, E.; Gorzelak-Pabiś, P.

Neuroprotective Effect of SGLT2

Inhibitors. Molecules 2021, 26, 7213.

https://doi.org/10.3390/

molecules26237213

Academic Editors: Alicja Nowaczyk and Grzegorz Grześk

Received: 3 November 2021

Accepted: 26 November 2021

Published: 28 November 2021

Publisher's Note: MDPI stays neutral with regard to jurisdictional claims in published maps and institutional affiliations.

Copyright: (C) 2021 by the authors Licensee MDPI, Basel, Switzerland. This article is an open access article distributed under the terms and conditions of the Creative Commons Attribution (CC BY) license (https:// creativecommons.org/licenses/by/ $4.0 /)$.
Laboratory of Tissue Immunopharmacology, Department of Internal Diseases and Clinical Pharmacology, Medical University of Lodz, Kniaziewicza 1/5, 91-347 Lodz, Poland; agnieszka.sanetra@stud.umed.lodz.pl (A.P.); ewelina.wozniak@umed.lodz.pl (E.W.); paulina.gorzelak-pabis@umed.lodz.pl (P.G.-P.)

* Correspondence: marlena.broncel@umed.lodz.pl; Tel.: +48-42251-60-03

\begin{abstract}
Patients with diabetes are at higher risk of cardiovascular diseases and cognitive impairment. SGLT2 inhibitors (Empagliflozin, Canagliflozin, Dapagliflozin, Ertugliflozin, Sotagliflozin) are newer hypoglycemic agents with many pleiotropic effects. In this review, we discuss their neuroprotective potential. SGLT2 inhibitors (SGLT2i) are lipid-soluble and reach the brain/serum ratio from 0.3 to 0.5 . SGLT receptors are present in the central nervous system (CNS). Flozins are not fully SGLT2selective and have an affinity for the SGLT1 receptor, which is associated with protection against ischemia/reperfusion brain damage. SGLT2i show an anti-inflammatory and anti-atherosclerotic effect, including reduction of proinflammatory cytokines, M2 macrophage polarization, JAK2/STAT1 and NLRP3 inflammasome inhibition, as well as cIMT regression. They also mitigate oxidative stress. SGLT2i improve endothelial function, prevent remodeling and exert a protective effect on the neurovascular unit, blood-brain barrier, pericytes, astrocytes, microglia, and oligodendrocytes. Flozins are also able to inhibit AChE, which contributes to cognitive improvement. Empagliflozin significantly increases the level of cerebral BDNF, which modulates neurotransmission and ensures growth, survival, and plasticity of neurons. Moreover, they may be able to restore the circadian rhythm of mTOR activation, which is quite a novel finding in the field of research on metabolic diseases and cognitive impairment. SGLT2i have a great potential to protect against atherosclerosis and cognitive impairment in patients with type 2 diabetes mellitus.
\end{abstract}

Keywords: SGLT2i; sodium-glucose cotransporter 2 inhibitors; neuroprotection; atheroprotection; mTOR; type 2 diabetes mellitus; cognitive impairment; inflammation; oxidative stress

\section{Introduction}

Type 2 diabetes mellitus (T2DM) is a chronic metabolic disease causing a variety of complications, including atherosclerosis which is associated with increased cardiovascular risk contributing to reduced life expectancy [1]. Additionally, atherosclerosis is an important factor leading to cognitive impairment in the elderly via several mechanisms such as ischemia and a direct molecular link [2,3]. Diabetes mellitus type 2 accelerates the development of atherosclerosis, and patients with T2DM are at a two to four times higher risk of developing vascular diseases than non-diabetics [4]. There is a lot of evidence that proves that diabetic patients are at an increased risk of developing cognitive impairment. Glucose metabolism is also impaired in Alzheimer's disease, as it is sometimes called 'Type 3 diabetes' or 'diabetes of the brain' [5]. According to a meta-analysis performed by Zhang J. et al., patients with diabetes mellitus type 2 have a 53\% higher relative risk of Alzheimer's disease than non-diabetic individuals (RR 1.53, 95\% CI: 1.42-1.63) [6]. Among diabetics, the presence of micro- and macrovascular complications increases the risk of cognitive decline even further, suggesting that vascular mechanisms, including atherosclerosis, are important players [7]. As diabetic patients with atherosclerosis are especially vulnerable to cognitive impairment, it is necessary to search for drugs that could ensure T2DM control, reduce cardiovascular risk and improve cognitive functions. 
SGLT2 inhibitors are newer hypoglycemic drugs that have revolutionized the clinical approach to T2DM management. Their main mechanism of action is inhibiting SGLT2 receptors in the proximal tubules of the kidneys and thus lowering blood glucose levels by blocking its reabsorption from the urine [8]. As it has been proved by large doubleblind clinical trials, Empagliflozin not only decreases $\mathrm{HbA1c}$ in diabetic patients but also improves their life expectancy by reducing cardiovascular mortality [9]. Canagliflozin, Dapagliflozin, Sotagliflozin significantly decrease the composed primary end-point, including cardiovascular mortality and other cardiovascular outcomes [10-12]. Ertugliflozin showed non-inferiority vs. placebo in reducing cardiovascular mortality and other cardiovascular outcomes [13]. The exact mechanism has not been fully established yet, and SGLT2 inhibitors show many additional beneficial effects which contribute to their wider use, even in non-diabetic patients [14]. There is growing evidence that SGLT2 inhibitors have a neuroprotective potential, as in a murine mixed model of diabetes mellitus and Alzheimer's disease, empagliflozin improved both cerebral microvascular and cognitive impairment [15]. There is no available data on the adverse effects flozins may exert on the Central Nervous System. The most commonly known side effects are genitourinary infections; however, rare but more serious effects also may occur, like euglycemic ketoacidosis [16]. In this review, we are focusing on SGLT2 inhibitors' potential to improve the impaired cognitive functions of diabetic patients with atherosclerosis.

\section{Neurological Potential of SGLT2 Inhibitors}

SGLT2 inhibitors are lipid-soluble and cross the blood-brain barrier reaching the brainto-serum ratio of the areas under the curves from 0.3 (Canagliflozin and Dapagliflozin) up to 0.5 (Empagliflozin) [17]. They have the ability to directly affect their target, since SGLT1 and SGLT2 co-receptors are expressed in the human central nervous system and play an important role in maintaining glucose homeostasis. SGLTs are responsible for the transport of glucose, galactose and sodium ions against the concentration gradients [18]. SGLT1 transports two Na+ ions with one D-glucose molecule and SGLT2 one sodium ion with one D-glucose [19]. They may be found in many areas of the central nervous system in several isoforms. SGLT1 inhibitors are present in the pyramidal cells of the brain cortex, Purkinje cerebellum cells, hippocampus pyramidal, and granular cells [20]. They were also detectable in glial cells in the ventromedial hypothalamus [21]. Brain expression of SGLT2 is lower than SGLT1, and it occurs mainly in the microvessels of the blood-brain barrier, but also in the amygdala, hypothalamus, periaqueductal gray (PAG), and in the dorsomedial medulla - the nucleus of the solitary tract (NTS) [22,23]. The presence of SGLT1/SGLT2 was also described in the abluminal membrane of the capillary endothelium [21]. Interestingly, the brain locations where SGLTs are present have been proven to be responsible for learning processes, food intake, energy and glucose homeostasis, and central cardiovascular and autonomic regulation [23,24]. The location of SGLT1 and SGLT2 receptors in the CNS is presented in Figure 1. It is possible that SGLT2 receptors also exert a cardioprotective effect through central mechanisms by directly influencing cardiovascular regulation and autonomic pathways, including the paraventricular nucleus of the hypothalamus, the nucleus of the solitary tract, and the periaqueductal gray [23]. An immunoblotting study of post-mortem human brain tissue showed a significant increase in SGLT1 and SGLT2 expression following brain injury [25]. Results of a study performed in a murine model suggest that, after a brain injury, SGLT1 blockage may bring beneficial effects with regard to the area of the brain lesions, the volume of damaged tissue, edema, and motoric disability [26]. 


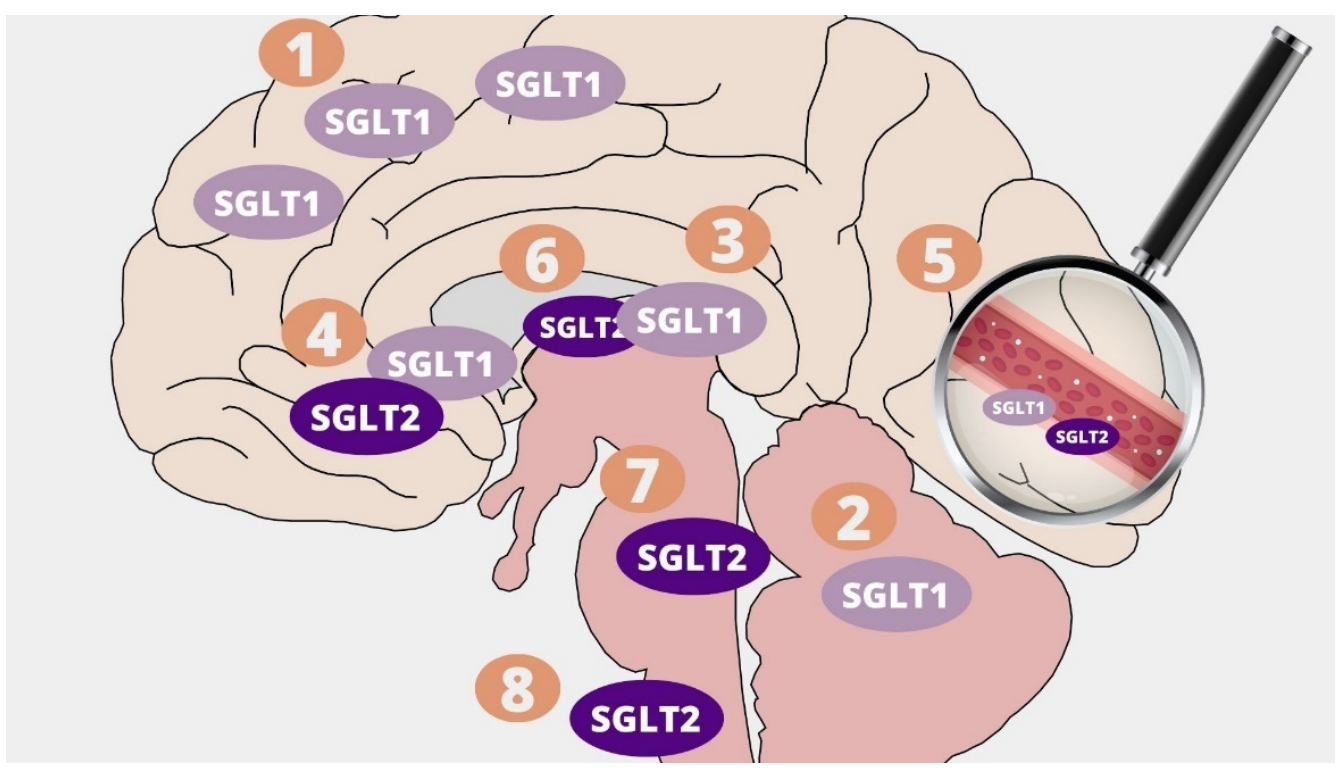

Figure 1. Distribution of SGLT1 and SGLT2 receptors in the Central Nervous System: 1. Pyramidal cells of brain cortex; 2 . Purkinje cerebellum cells; 3 . Hippocampus pyramidal and granular cells; 4 . Hypothalamus; 5. Microvessels; 6. Amygdala; 7. Periaqueductal grey; 8. Dorsomedial medulla—nucleus of the solitary tract (NTS).

SGLT2 inhibitors are not fully selective for SGLT2 co-receptors, and they also affect SGLT1 to various extents (Table 1). Sotagliflozin has the most affinity to SGLT1 receptors. It is even called a "dual SGLT1/SGLT2 inhibitor", however, it is the newest Flozin, and it is not yet used in diabetic patients on a large scale [12]. Among commonly used SGLT2 inhibitors, Canagliflozin has the greatest potential for inhibiting SGLT1 receptors. In contrast, Empagliflozin and Ertugliflozin are the most selective for SGLT2 and have the lowest potential for interaction with SGLT1 [27]. Therefore, theoretically, to obtain the neuroprotective effect associated with SGLT1 inhibition in diabetic patients, Sotagliflozin and Canagliflozin should be preferred over Dapagliflozin, Empagliflozin, and Ertugliflozin.

Table 1. Comparison of pleiotropic effects of Sotagliflozin, Canagliflozin, Dapagliflozin, Empagliflozin, Ertugliflozin.

\begin{tabular}{|c|c|c|c|c|c|}
\hline & Sotagliflozin & Canagliflozin & Dapagliflozin & Empagliflozin & Ertugliflozin \\
\hline $\begin{array}{l}\text { SGLT2 Selectivity } \\
\text { over SGLT1 }\end{array}$ & $\begin{array}{l}20 \text { fold } \\
\text { [28] }\end{array}$ & $\begin{array}{l}250 \text { fold } \\
\text { [28] }\end{array}$ & $\begin{array}{l}1200 \text { fold } \\
\text { [28] }\end{array}$ & $\begin{array}{l}2500 \text { fold } \\
\text { [28] }\end{array}$ & $\begin{array}{l}2500 \text { fold } \\
\text { [28] }\end{array}$ \\
\hline Brain/Serum Ratio & $\mathrm{n} / \mathrm{a}$ & 0.3 & 0.3 & 0.5 & $\mathrm{n} / \mathrm{a}$ \\
\hline AChE Inhibition & $\begin{array}{c}K_{\mathrm{i}} 5.6 \mu \mathrm{M} \\
{[29]}\end{array}$ & $\begin{array}{c}\text { The most potent, even } \\
\text { called a dual inhibitor } \\
K_{\mathrm{i}} 0.13 \mu \mathrm{M} \\
{[29]}\end{array}$ & $\begin{array}{c}K_{\mathrm{i}} 25.02 \mu \mathrm{M} \\
{[29]}\end{array}$ & $\begin{array}{c}K_{\mathrm{i}} 0.177 \mu \mathrm{M} \\
{[30]}\end{array}$ & $\begin{array}{c}K_{\mathrm{i}} 31.69 \mu \mathrm{M} \\
{[29]}\end{array}$ \\
\hline BDNF Increase & $\mathrm{n} / \mathrm{a}$ & $\mathrm{n} / \mathrm{a}$ & $\mathrm{n} / \mathrm{a}$ & $\begin{array}{l}\text { Yes } \\
{[31]}\end{array}$ & $\mathrm{n} / \mathrm{a}$ \\
\hline $\begin{array}{l}\text { Anti-epileptic } \\
\text { Potential }\end{array}$ & $\mathrm{n} / \mathrm{a}$ & $\mathrm{n} / \mathrm{a}$ & $\begin{array}{l}\text { Yes } \\
{[32]}\end{array}$ & $\mathrm{n} / \mathrm{a}$ & $\mathrm{n} / \mathrm{a}$ \\
\hline CIMT Regression & $\mathrm{n} / \mathrm{a}$ & $\mathrm{n} / \mathrm{a}$ & $\begin{array}{l}\text { Yes } \\
{[33]}\end{array}$ & $\begin{array}{l}\text { Yes } \\
{[34]}\end{array}$ & $\mathrm{n} / \mathrm{a}$ \\
\hline Anti-inflammatory & $\mathrm{n} / \mathrm{a}$ & $\begin{array}{l}\text { Yes } \\
{[35]}\end{array}$ & $\begin{array}{l}\text { Yes } \\
{[36]}\end{array}$ & $\begin{array}{l}\text { Yes } \\
{[37]}\end{array}$ & $\begin{array}{c}\text { Noln/a } \\
\text { [38] }\end{array}$ \\
\hline $\begin{array}{l}\text { Blood-brain Barrier } \\
\text { Protection }\end{array}$ & $\mathrm{n} / \mathrm{a}$ & $\mathrm{n} / \mathrm{a}$ & $\mathrm{n} / \mathrm{a}$ & $\begin{array}{c}\text { Yes } \\
{[37]}\end{array}$ & $\mathrm{n} / \mathrm{a}$ \\
\hline
\end{tabular}


Table 1. Cont.

\begin{tabular}{|c|c|c|c|c|c|}
\hline & Sotagliflozin & Canagliflozin & Dapagliflozin & Empagliflozin & Ertugliflozin \\
\hline $\begin{array}{l}\text { NLRP3 Inflammasome } \\
\text { Inhibition }\end{array}$ & $\mathrm{n} / \mathrm{a}$ & $\mathrm{n} / \mathrm{a}$ & $\begin{array}{l}\text { Yes } \\
{[39]}\end{array}$ & $\begin{array}{l}\text { Yes } \\
{[40]}\end{array}$ & $\mathrm{n} / \mathrm{a}$ \\
\hline $\begin{array}{l}\text { Promoting M2 } \\
\text { Macrophages } \\
\text { Polarization }\end{array}$ & $\mathrm{n} / \mathrm{a}$ & $\begin{array}{l}\text { Yes } \\
{[41]}\end{array}$ & $\begin{array}{l}\text { Yes } \\
{[42]}\end{array}$ & $\begin{array}{l}\text { Yes } \\
{[43]}\end{array}$ & $\mathrm{n} / \mathrm{a}$ \\
\hline $\begin{array}{l}\text { Oxidative Stress } \\
\text { Reduction }\end{array}$ & $\begin{array}{l}\text { Yes } \\
{[44]}\end{array}$ & $\begin{array}{l}\text { Yes } \\
{[45]}\end{array}$ & $\begin{array}{l}\text { Yes } \\
{[46]}\end{array}$ & $\begin{array}{l}\text { Yes } \\
{[47]}\end{array}$ & $\begin{array}{l}\text { Yes } \\
{[48]}\end{array}$ \\
\hline $\begin{array}{l}\text { Neurovascular Unit } \\
\text { Remodeling }\end{array}$ & $\mathrm{n} / \mathrm{a}$ & $\mathrm{n} / \mathrm{a}$ & $\mathrm{n} / \mathrm{a}$ & $\begin{array}{l}\text { Yes } \\
{[49]}\end{array}$ & $\mathrm{n} / \mathrm{a}$ \\
\hline $\begin{array}{c}\text { Cerebral } \\
\text { Ischemia/Reperfusion } \\
\text { Damage Reduction }\end{array}$ & $\mathrm{n} / \mathrm{a}$ & $\mathrm{n} / \mathrm{a}$ & $\mathrm{n} / \mathrm{a}$ & $\begin{array}{l}\text { Yes } \\
{[50]}\end{array}$ & $\mathrm{n} / \mathrm{a}$ \\
\hline $\begin{array}{l}\text { Reduced mTOR } \\
\text { Signaling }\end{array}$ & $\mathrm{n} / \mathrm{a}$ & $\begin{array}{l}\text { Yes } \\
{[51]}\end{array}$ & $\begin{array}{l}\text { Yes } \\
{[51]}\end{array}$ & $\begin{array}{l}\text { Yes } \\
{[52]}\end{array}$ & $\begin{array}{c}\text { Yes } \\
{[53]}\end{array}$ \\
\hline
\end{tabular}

In the central nervous system, there is also a place for selective SGLT2 inhibitors since, based on the results obtained by Erdogan MA. et al., Dapagliflozin significantly reduces seizure activity, both at the electrophysiological and clinical level, in a rat model of epilepsy [32]. It may be associated with a similar effect of glucose fasting-like metabolic switch as the one observed in ketogenic diets, which in some circumstances also improve brain seizure activity [54]. There is no clinical data comparing the efficacy of ketogenic diets and dapagliflozin therapy on brain epileptic activity; however, adhering to a ketogenic diet is difficult and has to be closely monitored. On the contrary, dapagliflozin is a safe drug widely used in diabetic patients. Interestingly, cognitive impairment shares the same risk factors as epilepsy and atherosclerosis, and commonly used anti-epileptic drugs such as phenytoin, carbamazepine, valproic acid are associated with increased cardiovascular risk [55]. Dapagliflozin may be a preferable flozin in diabetic patients with epilepsy as it has an anti-epileptic potential. Moreover, it significantly reduces cardiovascular risk and thus may prevent cognitive decline.

There is in vivo evidence for the expression of SGLT2 protein in choroid plexus epithelial cells and ependymal cells of the human brain [56]. This is crucial information indicating that SGLT2 may have an influence on the composition of the cerebrospinal fluid (CSF), whose role in the pathology of neurodegenerative disorders provides a new direction for research and requires further investigation [57].

There is growing evidence that apart from direct mechanisms of SGLT2 inhibitors in the central nervous system, they also exert a beneficial pleiotropic effect. In silico studies indicate that flozins have the molecular ability to inhibit acetylcholinesterase. Canagliflozin was even called a 'dual inhibitor of SGLT2 and AChE' as its estimated inhibition constant $K_{\mathrm{i}}$ (i.e., the concentration required to produce half-maximum inhibition) against $\mathrm{AChE}$ was $0.12859 \mu \mathrm{M}$ [58]. It is clinically relevant as patients taking canagliflozin reach a serum drug concentration of $10 \mu \mathrm{M}$, and the brain/serum ratio of canagliflozin is 0.3 . Therefore, the amount of canagliflozin penetrating the brain $(3 \mu \mathrm{M})$ is enough to inhibit AChE [17,59]. As for other SGLT2i, the $K_{\mathrm{i}}$ for inhibiting AChE is $0.177 \mu \mathrm{M}$ for empagliflozin and $25.02 \mu \mathrm{M}$ for dapagliflozin, and brain concentrations are $0.5 \mu \mathrm{M}$ and $0.3 \mu \mathrm{M}$, respectively, so out of those two, only in the case of empagliflozin, brain concentration is enough to inhibit AChE (Table 1) $[17,30,60]$. Patients with Alzheimer's disease have a reduced amount of acetylcholine neurotransmitters in the brain, and acetylcholinesterase inhibitors including donepezil, rivastigmine, galantamine are commonly used to increase the acetylcholine level and improve cognition [61]. In a rat model of cognitive impairment induced by scopolamine, canagliflozin, similarly to galantamine, decreased AChE activity, increased acetylcholine $\mathrm{M} 1$ receptor (M1 mAChR) and monoamines levels. It also improved cognitive 
functions in the $\mathrm{Y}$ maze task and water maze task [62]. Canagliflozin has the greatest potential of inhibiting $\mathrm{AChE}$ and may be a preferable solution in patients with T2DM who would also benefit from the inhibition of acetylcholinesterase.

Another promising effect SGLT2i exert on the central nervous system was described by Lin B. et al., for empagliflozin, which significantly increased cerebral BDNF (Brain-derived neurotrophic factor) levels in $\mathrm{db} / \mathrm{db}$ mice (Table 1 ). Moreover, this effect was accompanied by improvement in cognitive functions [31]. BDNF takes part in the growth, survival, and plasticity of neurons as well as in the modulation of neurotransmission. It is an important factor for the processes of learning and memorizing [63]. Interestingly, a significant decline of BDNF was observed in patients with T2DM, and it was associated with cognitive impairment, which was not observed in non-diabetic controls [64]. Surprisingly, BDNF is crucial not only for the central nervous system but also for atherosclerosis. Patients with DMAS (Diabetes Mellitus Accelerated Atherosclerosis) had a lower expression of BDNF, and it was negatively correlated with inflammation. In the same study, supplementation of BDNF in mice significantly reduced atherosclerotic lesions [65]. The anti-inflammatory properties of BDNF are probably associated with promoting M2 macrophages polarization via STAT3 [65]. SGLT2i may thus bring benefits to diabetic patients with atherosclerosis by preventing cognitive impairment associated with low levels of BDNF.

\section{Atherosclerosis, Cognitive Impairment, and SGLT2i}

The presence of cholesterol-rich plaques in the walls of large cerebral arteries is defined as Cerebral Atherosclerosis (CA). In previous studies, atherosclerotic lesions in intraand extra-cranial arteries were associated with cognitive impairment and even dementia $[2,66,67]$. According to results obtained by Dearborn JL. et al., atherosclerotic plaques in the anterior cerebral artery occurred independently of vascular risk factors associated with increased prevalence of dementia (RPR $3.8195 \%$ CI [1.57-9.23] $p=0.003$ ) in elderly patients [2]. On the other hand, atherosclerosis in the posterior cerebral artery increased the risk of Mild Cognitive Impairment (MCI) (RPR 1.44 95\% CI [1.04-1.98] $p=0.027$ ) [2]. As demonstrated by another study, dementia occurred more frequently in patients with atherosclerotic calcifications in intra and extra-cranial arteries as opposed to coronary vessels [66]. Cerebral atherosclerosis and dementia are related to each other; however, the exact mechanism remains unknown. In reference to the proteomic sequencing of the dorsolateral prefrontal cortex of 438 humans performed by Wingo A.P. et al., CA was associated with reduced synaptic function, excess myelination, and axonal injury independently of ischemia [67]. Preventing atherosclerosis would contribute to the improvement in cognitive functions in elderly people. Results obtained by Sabia S. et al. show that cardiovascular health at the age of 50 years is crucial for further development of cognitive impairment [68]. As mentioned before, SGLT2i significantly reduce cardiovascular risk. They exert a pleiotropic anti-atherosclerotic effect by reducing vascular inflammation, oxidative stress and improving endothelial dysfunction [69]. In a previous study including diabetic patients, a three-month treatment with empagliflozin resulted in a significant regression of complex intima media thickness (cIMT) by $7.9 \%$; $p<0.0001$. Interestingly, this effect was significant just after one month of empagliflozin therapy [34]. CIMT is a relevant marker of early atherosclerosis, and it is often measured in the carotid arteries [70]. According to Feinkohl I. et al., cIMT is also a significant predictor of cognitive decline in patients with T2DM [71]. Future studies should evaluate the clinical relevance of the ability of SGLT2 to reduce atherosclerotic lesions and thus the impact on cognitive functions.

\section{Inflammation}

The inflammatory process in the central nervous system also referred to as neuroinflammation, is associated with a lot of pathologies, including cognitive dysfunction. In a study conducted by Suridjan I. et al., and including patients with Alzheimer's disease, the presence of neuroinflammation detected by [18F]-FEPPA was positively correlated with the level of cognitive decline [72]. There is growing evidence that the presence of 
inflammation outside the central nervous system (systemic inflammation) can also contribute to a decline in cognitive functions [73]. According to Walker K. et al., elevated inflammatory markers in middle adulthood resulted in significant cognitive decline after 20 years [74]. The neurovascular unit (NVU), which is composed of endothelial cells lining brain microvessels as well as neurons, microglia, astrocytes, and pericytes, mediates homeostasis by regulating traffic between blood and the neural environment. Systemic inflammation is associated with circulating proinflammatory cytokines, which impair the endothelium of brain microvessels, increase the permeability of the blood-brain barrier and change the phenotype of astrocytes and microglia into pro-inflammatory ones [75]. M1 activated microglia impair NVU by secreting proinflammatory cytokines, including TNF- $\alpha$, IL-1 $\beta$, IL-6, IL-18, which contribute to neurodegeneration by breaking neurotransmitters into bioactive metabolites, tau hyperphosphorylation, $\beta$-amyloid oligomerization, and complement activation [76,77]. In a mouse model of T2DM, empagliflozin had a protective effect, involving remodeling prevention on the neurovascular unit, the blood-brain barrier, pericytes, astrocytes, microglia, and oligodendrocytes [49]. The inflammatory process is also a key driver of atherosclerosis. In the CANTOS study, inhibition of interleukin- $1 \beta$ with canakinumab significantly reduced cardiovascular risk independently of lipid levels [78]. Proinflammatory cytokines including TNF- $\alpha$, IL-1 $\beta$, IL- 6 are also a mediator of atherosclerosis since they activate endothelial cells, attract monocytes, and facilitate their adhesion by up-regulating MCP-1, ICAM, VCAM [79]. There is abundant evidence from animal studies showing that SGLT2 inhibitors slow down the progression of atherosclerosis and exert an anti-inflammatory effect by reducing the expression of proinflammatory cytokines, including TNF- $\alpha$, IL-1 $\beta$, IL-6, MCP-1, ICAM, VCAM [69]. In humans, the serum level of IL-6 dropped by $26.6 \%(p=0.010)$ after 2 years of canagliflozin treatment [35].

NLRP3 (NOD-, LRR- and pyrin domain- containing protein 3) inflammasome activation is one of the key molecular pathways mediating inflammation as it leads to the release of IL-1 $\beta$ and IL-18 cytokines. It is a crucial element of the innate immune system activated not only by microbial infection or cellular damage but also by chronic inflammatory diseases, including atherosclerosis and Alzheimer's disease [80]. NLRP3 is an important mechanism that drives inflammation in atherosclerosis since activation of this pathway in arterial walls by lipoproteins triggers inflammatory response [81]. In a mouse model of atherosclerosis, the inhibition of the NLRP3 inflammasome by MCC950 resulted in a significant reduction in atherosclerotic lesions [82]. In Alzheimer's disease, NLRP3 inflammasome links systemic inflammation with neuroinflammation and impairs the removal of amyloid-beta by the microglia [83]. This effect may be clinically significant, as, in another study, the inhibition of NLRP3 by OLT1177 significantly improved cognitive impairment in a mouse model of Alzheimer's disease [84]. SGLT2 inhibitors may improve atherosclerosis and cognitive dysfunction via NLRP3 inflammasome inhibition (Table 1). As proven by Kim S. et al., in the ex vivo study in diabetic patients, empagliflozin significantly attenuated the inflammasome activity after 30 days of treatment [40].

Macrophages play a central role in atherosclerosis due to their foam cell formation in the vascular lesions. They are also an important factor in the pathology of cognitive impairment associated with Alzheimer's disease as their infiltration is increased in patients with $\mathrm{AD}$ being most abundant in the brain regions rich in $\mathrm{A} \beta$ plaques [85]. Macrophages are immune cells responsible for mediating chronic low-grade inflammation and residual cardiovascular risk, which remains after lipid reduction. They are characterized by an ability to change in response to the environment. There are two immunological types of macrophages, i.e., M1 and M2 macrophages. M1 proinflammatory macrophages secrete $1 \beta$, IL-6, and TNF- $\alpha$, maintain a chronic inflammatory state, and promote atherogenesis. On the contrary, M2 macrophages have an anti-inflammatory and atheroprotective profile by secreting IL-1 receptor agonist, IL-10, and collagen [86]. SGLT2 inhibitors have been proven to strongly promote macrophage polarization towards M2 and thus alleviate inflammation and atherosclerosis (Table 1) [42]. In the central nervous system, M1 polarization of glial cells was associated with neurodegeneration [73]. M1 polarized macrophages activate 
STAT-1, which is a proinflammatory transcription factor [87]. It can also be involved in cognitive impairment in Alzheimer's disease since it is activated by intracellular Tau accumulation. In a murine model, depletion of STAT-1 activation significantly reduced synaptic dysfunction and cognitive impairment associated with Tau accumulation [88]. Empagliflozin was proven to mitigate inflammation by downregulation of the JAK2/STAT1 pathway in macrophages [89]. Macrophages take part in cognitive impairment as perivascular macrophages (PVM) are the source of vascular oxidative stress by producing a large amount of free radicals near the neurovascular unit [90]. They also affect the permeability of the blood-brain barrier [91]. In previous studies, depletion of perivascular macrophages prevented short-term memory impairment in a murine model [92]. SGLT2 inhibitors may possibly attenuate atherosclerosis and cognitive impairment via macrophages by promoting M2 polarization and downregulating STAT-1 (Figure 2).

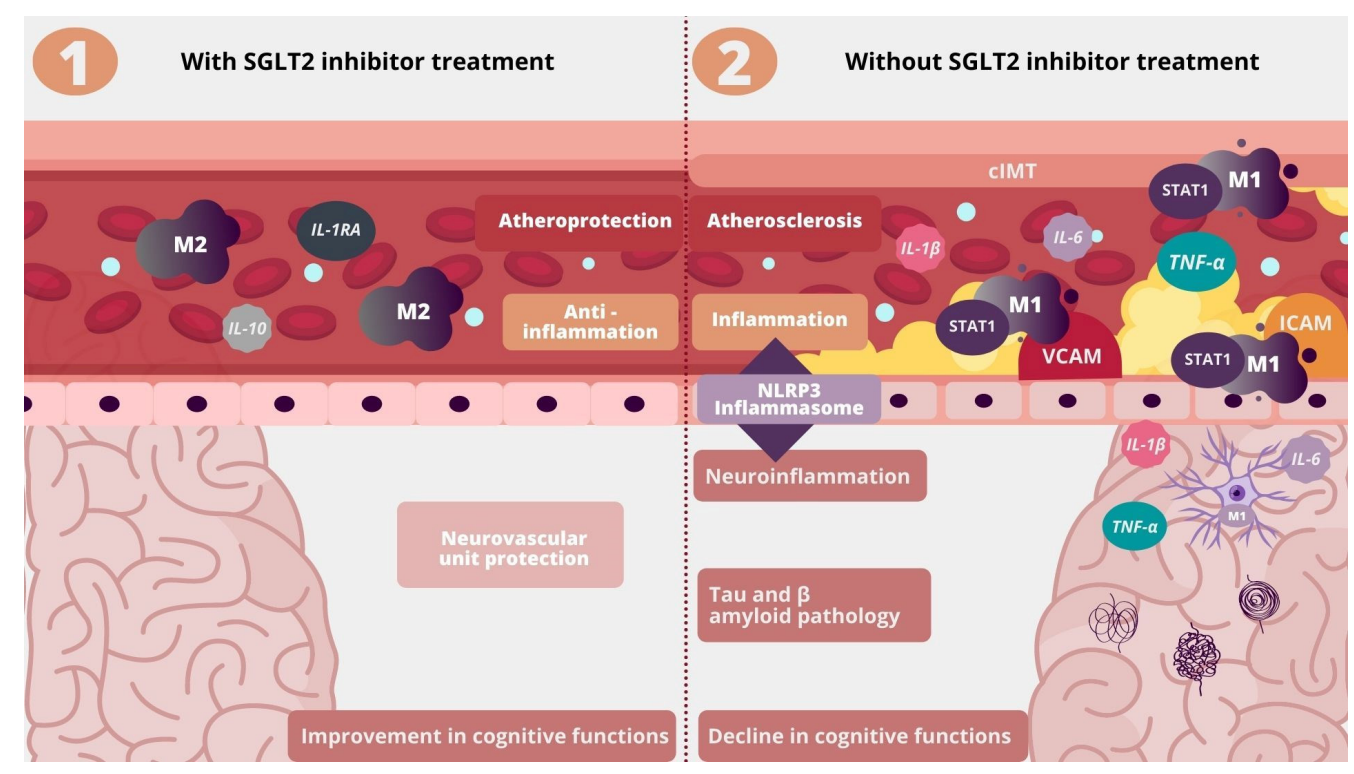

Figure 2. Influence of SGLT2 inhibitors on inflammation, atherosclerosis, and neuroinflammation. IL-1RA-Interleukin 1 Receptor Agonist, cIMT—carotid intima-media thickness, STAT1—Signal transducer and activator of transcription 1, VCAM-Vascular Cell Adhesion Molecule; ICAMIntracellular Adhesion Molecule.

\section{Oxidative Stress and Mitochondrial Dysfunction}

A chronic inflammatory state also contributes to oxidative damage as it causes the release of reactive oxygen species (ROS) [93]. The overproduction of ROS or decrease in the anti-oxidant defense results in oxidative stress, which is a significant contributor to vascular diseases, including atherosclerosis, as it causes endothelial dysfunction, promotes remodeling and further enhances inflammation [94]. Oxidative stress is also associated with $\mathrm{A} \beta$ - or tau -induced neurotoxicity since it facilitates their aggregation, phosphorylation, and polymerization. These processes contribute to neurodegeneration which results in impaired synaptic plasticity, neuroinflammation, neurotransmitter imbalance, neuronal and synaptic loss leading to cognitive impairment [95]. In the previous study, the increased level of oxidative stress was associated with cognitive decline in a healthy population [96]. Interestingly, SGLT2 inhibitors were proven to ameliorate oxidative stress not only by maintaining a normal glucose level but also by reducing the generation of free radicals (Table 1) [97]. In patients with T2DM, empagliflozin significantly enhanced leukocyte expression of antioxidative enzymes including glutathione s-reductase and catalase and simultaneously reduced pro-oxidative myeloperoxidase after four months of treatment [47].

Mitochondrial function is crucial for maintaining neuronal homeostasis, as neurons are vulnerable to bioenergetic changes. Mitochondrial dysfunction plays an important role in the pathogenesis of neurodegenerative diseases; there is even a "Mitochondrial 
Cascade hypothesis" in Alzheimer's Disease pathology [98]. In a murine model, depletion of AIF (apoptosis-inducing factor), which is a mitochondrial protein taking part in apoptosis and electron transport chain, was associated with serious disturbances in hippocampal-dependant spatial learning and memory [99]. In a rat model, taking dapagliflozin was associated with significant improvement in brain mitochondrial function, including decreased ROS production, mitochondrial swelling, and mitochondrial membrane depolarization [100]. The existing evidence supports the concept that SGLT2 may improve atherosclerosis and cognitive impairment by reduction in oxidative stress and improvement in mitochondrial dysfunction.

\section{6. mTOR Signaling}

mTOR (mechanistic/mammalian target of rapamycin) is a novel, promising molecular pathway linking metabolic diseases and cognitive impairment. It is a crucial cellular coordinator of systemic energy status and local nutrients. Chronic up-regulation of mTOR is present in an anabolic state (increased levels of glucose, amino acids, growth factors) associated with over-nutrition and lack of physical activity [101]. Continuous activation of mTOR causes endothelial cell dysfunction, which is not only a key point of atherosclerosis but also contributes to interruption in the blood-brain barrier [102]. Unrestrained mTOR up-regulation has also been linked to tau and amyloid $\beta$ hyperphosphorylation and aggregation in Alzheimer's disease [103]. Moreover, chronic mTOR activation impairs lysosomal protein degradation, which supports the "Endo-Lysosomal Dysfunction" hypothesis of Alzheimer's Disease [104]. It is believed that restoring the circadian rhythm of mTOR activation would be beneficial in metabolic diseases and cognitive impairment. This effect can be achieved by increasing physical activity, reducing calories intake, or intermittent fasting. All the abovementioned interventions require the patient's determination and are difficult to obtain in real-life clinical practice. SGLT2 inhibitors are able to mimic those states by promoting catabolism and restoring mTOR cycling, thus decreasing cognitive impairment associated with metabolic diseases [105]. An interesting SGLT2i effect was noticed by Esterline R. et al.; SGLT2 inhibitors cause loss of glucose with urine, but simultaneously they activate glycogenolysis and gluconeogenesis and thus increase fasting endogenous glucose production, which occurs particularly at night. This effect contributes to switching metabolism from anabolic to catabolic depending not on glucose and insulin but on fatty acid oxidation and leads to a decrease in mTOR fuel: blood insulin and amino-acids. Nocturnal mTOR suppression is followed by daily activation, and this state allows maintaining mitochondrial and lysosomal homeostasis (Figure 3) [104]. Additionally, according to Packer M, SGLT2 inhibitors cause transcriptional changes in cells that occur during starvation, which is called "state of fasting mimicry" and include SIRT/AMPK activation and Akt/mTOR suppression (Figure 3). Moreover, taking flozins causes changes similar to an ischemic state, including HIF- $2 \alpha$ activation which stimulates erythropoiesis, and patients with higher erythrocyte count benefited most from SGLT2i therapy. Interestingly those effects occurred also in cells, which do not express SGLT [106]. There is a lot of evidence that SGLT2 inhibitors are able to suppress mTOR (Table 1). Flozins, by restoring the circadian rhythm of mTOR activity, seem to bring benefits in patients with Alzheimer's Disease according to "Type 3 Diabetes Hypothesis", "Mitochondrial Cascade Hypothesis" and "Endo-Lysosomal Dysfunction Hypothesis" [105]. 


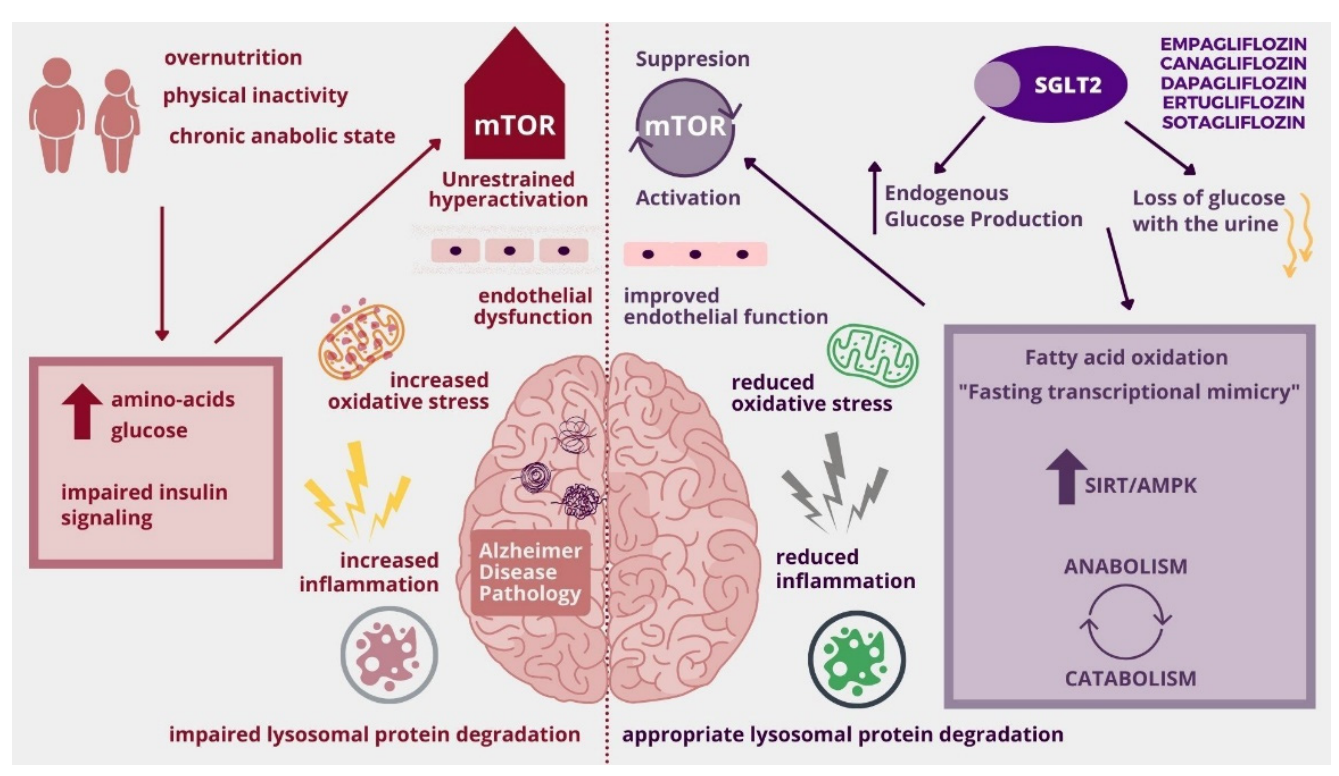

Figure 3. Influence of SGLT2 inhibitors on unrestrained activation of mTOR (mechanistic/mammalian target of rapamycin). AMPK-AMP-activated protein kinase, SIRT-Sirtuin.

\section{Cerebrovascular Dysfunction}

Cerebrovascular dysfunction is a pathological condition of the brain related to vascular pathology. A hyperglycemic state impairs the microvascular structure of the brain causing neurovascular remodeling, including loss of endothelial integrity, basement membrane thickening, loss of myelin and neurons, astrocytes and pericytes disturbance [107]. Such ultrastructural changes are associated with cognitive decline [108]. In a mouse model of T2DM, empagliflozin exerted a neuroprotective effect on neurovascular remodeling [49].

Cerebrovascular dysfunction is mainly associated with disturbed blood flow being either ischemia or bleeding. The presence of atherosclerotic lesions within arterial walls impairs cerebral blood flow and causes cerebrovascular dysfunction [109]. Most ischemic strokes are caused by atherosclerosis. According to a meta-analysis, the presence of carotid atherosclerosis was associated with an increased risk of recurrent stroke (OR: 2.87; 95\% CI $(2.42-3.37) ; p<0.00001)$ [110]. Acute ischemic stroke leads to a critical limitation of blood supply, which results in neuronal cell death and cognitive decline. Cognitive impairment affects $20-80 \%$ of patients after acute brain ischemia [111]. Although SGLT2 inhibitors do not reduce the risk of ischemic stroke incidence, they affect the most important cerebrovascular risk factors, including hyperglycemia, hypertension, obesity, dyslipidemia, and atherosclerosis [112]. Hypertension is the most common risk factor of stroke [113]. SGLT2 inhibitors significantly lower systolic and diastolic blood pressure without reflex activation of the sympathetic nervous system and are even able to change the non-dipping to dipping circadian blood pressure profile. While the exact mechanism of the antihypertensive effect of SGLT2 inhibitors has not been clearly established, it is considered that the most important factors are osmotic diuresis (induced by glucosuria) and natriuresis. Other features of SGLT2 inhibitors that contribute to lowering blood pressure are suppression of the renin-angiotensin system, decreased activity of the sympathetic system, antioxidative activity, and improvement in endothelial cell function [114]. Moreover, SGLT2 inhibitors may improve brain damage and cognitive impairment in patients after a stroke. SGLT receptors are important in ischemia-reperfusion cerebral damage. As presented in a mouse model of subcortical white matter infarct with cognitive impairment, the knockout of the SGLT1 receptor was associated with a lower expression of proinflammatory cytokines and better cognitive performance [115]. SGLT1 receptors mediate sodium influx, which causes depolarization and contributes to neuronal cell death during ischemia. According to Yamazaki Y. et al., increased sodium influx via the SGLT1 receptor was associated with more exacerbated neuronal damage, which was not observed in SGLT-1 knockdown mice 
(Figure 4) [116]. In a study assessing cerebral ischemia/reperfusion damage in a rat model, empagliflozin, in a dose-dependant manner, reduced neuronal death, infarct size and ameliorated cognitive impairment via HIF-1 $\alpha$ /VEGF signaling [50]. SGLT2 inhibitors may preserve cognitive functions in diabetic patients by preventing neurovascular remodeling and reducing the well-known risk factors of stroke. They can also bring benefits to post-stroke patients by reducing inflammation, sodium influx, and HIF-1 $\alpha$ /VEGF pathway.

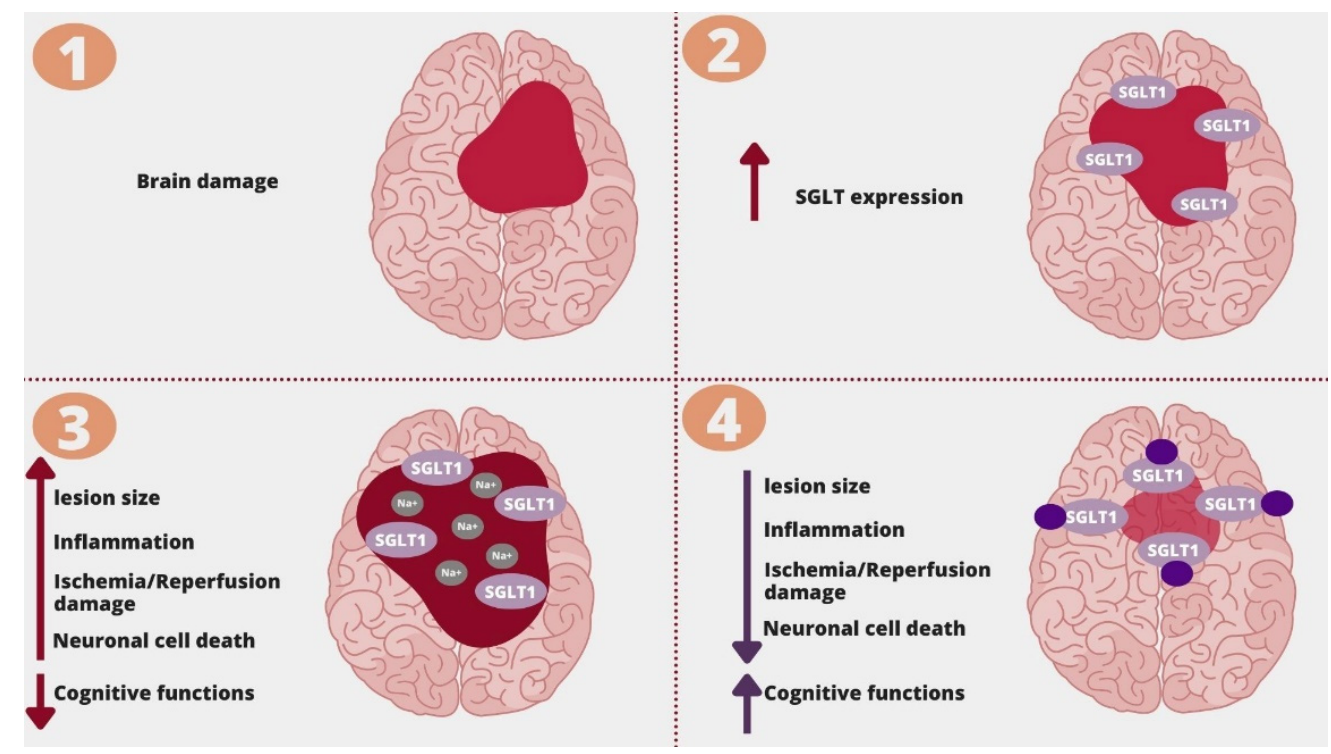

Figure 4. SGLT1 inhibition and ischemic brain damage. 1. Brain damage; 2 . In the area of brain damage, there is an increase in the expression of SGLT1; 3. Sodium influx through SGLT1 receptors is associated with increased ischemia/reperfusion damage, lesion size, edema, inflammation, neuronal cell death, and decline in cognitive functions; 4 . SGLT receptor blockage/knockdown was associated with improvement in damages caused by ischemia and ischemia/reperfusion damage.

\section{The Effect of SGLT2i on Alzheimer's Disease Pathology}

SGLT2 inhibitors can possibly bring benefits in patients with Alzheimer's Disease using the abovementioned mechanisms, including not only anti-inflammatory, anti-oxidative or atheroprotective effects, but also direct neuroprotective effects including BDNF increase and AChE inhibition. Additionally, SGLT2i can also be favorable for AD patients by improving brain insulin sensitivity [100]. Insulin resistance is present in 8 out of 10 patients suffering from Alzheimer's Disease [117]. Peripheral resistance to insulin also occurs in the CNS, as the glucose metabolic rate is reduced in the brains of AD patients in fluorodeoxyglucose positron emission tomography (FDG PET) $[118,119]$. Increased insulin level in the brain contributes to Alzheimer's Disease pathology, as the insulin-degrading enzyme (IDE) also takes part in degrading senile plaques, and in insulin resistance, it is involved in degrading insulin [117]. Moreover, insulin resistance is associated with activating GSK3- $\beta$ (glycogen synthase kinase $3 \beta$ ) signaling, which takes part in tau phosphorylation and $\mathrm{A} \beta$ production and $\mathrm{A} \beta$ mediated neuronal damage $[117,120]$. SGLT2 inhibition reduced GSK3- $\beta$ activity in hepatocytes [121]. In previous studies involving murine models, SGLT2i treatment caused a significant reduction in AD pathology, including tau phosphorylation and senile plaques density. This effect was associated with the improvement in cognitive functions, including memory and learning processes in the new object discrimination test and Morris water maze test [15].

\section{Summary}

Type 2 Diabetes Mellitus, atherosclerosis, and cognitive impairment still remain global health problems as they are chronic, incurable diseases leading to a reduction in life quality and expectancy. All these diseases share many pathological pathways. In the era of tailored- 
made therapies and novel drugs with numerous pleiotropic effects, it is very important to seek for shared molecular pathways of commonly occurring diseases and redefine indications for commonly used medications since such solutions may be beneficial for patients. In this review, we have discussed the role of SGLT2 inhibitors used in diabetic patients for the prevention of atherosclerosis and cognitive impairment. Flozins may bring positive effects in T2DM, atherosclerosis, and cognitive impairment through several mechanisms, including anti-inflammatory and anti-atherosclerotic properties, SGLT1 inhibition, AChE inhibition, reduction in oxidative stress, amelioration cerebrovascular remodeling and restoring a balance between catabolism and anabolism. However, long-term clinical trials are necessary to establish whether the above-mentioned mechanisms are clinically relevant since atheroprotective and neuroprotective effects will not be immediate and require a longterm SGLT2i intake. Currently, the University of Kansas Medical Center (NCT03801642) is conducting a clinical trial on dapagliflozin in patients with Alzheimer's disease.

Funding: This research received no external funding.

Conflicts of Interest: The authors declare no conflict of interest.

\section{References}

1. Einarson, T.R.; Acs, A.; Ludwig, C.; Panton, U.H. Prevalence of cardiovascular disease in type 2 diabetes: A systematic literature review of scientific evidence from across the world in 2007-2017. Cardiovasc. Diabetol. 2018, 17, 1-19. [CrossRef] [PubMed]

2. Dearborn, J.L.; Qiao, Y.; Suri, M.F.K.; Liu, L.; Mosley, T.H.; Alonso, A.; Knopman, D.S. Intracranial atherosclerosis and dementia The Atherosclerosis Risk in Communities (ARIC) Study. Am. Acad. Neurol. 2017, 88, 1556-1563.

3. Iadecola, C. Revisiting atherosclerosis and dementia. Nat. Neurosci. 2020, 23, 691-692. [CrossRef] [PubMed]

4. Bertoluci, M.C.; Rocha, V.Z. Cardiovascular risk assessment in patients with diabetes. Diabetol. Metab. Syndr. 2017, 9, 1-13. [CrossRef]

5. Nguyen, T.T.; Ta, Q.T.H.; Nguyen, T.K.O.; Nguyen, T.T.D.; Van Giau, V. Type 3 diabetes and its role implications in alzheimer's disease. Int. J. Mol. Sci. 2020, 21, 3165. [CrossRef] [PubMed]

6. Zhang, J.; Chen, C.; Hua, S.; Liao, H.; Wang, M.; Xiong, Y.; Cao, F. An updated meta-analysis of cohort studies: Diabetes and risk of Alzheimer's disease. Diabetes Res. Clin. Pract. 2017, 124, 41-47. [CrossRef] [PubMed]

7. Exalto, L.G.; Biessels, G.J.; Karter, A.J.; Huang, E.S.; Katon, W.J.; Minkoff, J.R.; Whitmer, R.A. Risk score for prediction of 10 year dementia risk in individuals with type 2 diabetes: A cohort study. Lancet Diabetes Endocrinol. 2013, 1, 183-190. [CrossRef]

8. Hsia, D.S.; Grove, O.; Cefalu, W.T. An Update on SGLT2 Inhibitors for the Treatment of Diabetes Mellitus. Curr Opin Endocrinol Diabetes Obes 2017, 24, 73-79. [CrossRef] [PubMed]

9. Steiner, S. Empagliflozin, cardiovascular outcomes, and mortality in type 2 diabetes. Z. Gefassmedizin 2016, 13, 17-18. [CrossRef]

10. Mahaffey, K.W.; Neal, B.; Perkovic, V.; De Zeeuw, D.; Fulcher, G.; Erondu, N.; Shaw, W.; Fabbrini, E.; Sun, T.; Li, Q.; et al. Canagliflozin for Primary and Secondary Prevention of Cardiovascular Events: Results from the CANVAS Program (Canagliflozin Cardiovascular Assessment Study). Circulation 2018, 137, 323-334. [CrossRef]

11. Wiviott, S.D.; Raz, I.; Bonaca, M.P.; Mosenzon, O.; Kato, E.T.; Cahn, A.; Silverman, M.G.; Zelniker, T.A.; Kuder, J.F.; Murphy, S.A.; et al. Dapagliflozin and Cardiovascular Outcomes in Type 2 Diabetes. N. Engl. J. Med. 2019, 380, 347-357. [CrossRef] [PubMed]

12. Bhatt, D.L.; Szarek, M.; Steg, P.G.; Cannon, C.P.; Leiter, L.A.; McGuire, D.K.; Lewis, J.B.; Riddle, M.C.; Voors, A.A.; Metra, M.; et al. Sotagliflozin in Patients with Diabetes and Recent Worsening Heart Failure. N. Engl. J. Med. 2021, 384, 117-128. [CrossRef]

13. Cannon, C.P.; Pratley, R.; Dagogo-Jack, S.; Mancuso, J.; Huyck, S.; Masiukiewicz, U.; Charbonnel, B.; Frederich, R.; Gallo, S.; Cosentino, F.; et al. Cardiovascular Outcomes with Ertugliflozin in Type 2 Diabetes. N. Engl. J. Med. 2020, 383, 1425-1435. [CrossRef] [PubMed]

14. Heerspink, H.J.L.; Stefánsson, B.V.; Correa-Rotter, R.; Chertow, G.M.; Greene, T.; Hou, F.-F.; Mann, J.F.E.; McMurray, J.J.V.; Lindberg, M.; Rossing, P.; et al. Dapagliflozin in Patients with Chronic Kidney Disease. N. Engl. J. Med. 2020, 383, 1436-1446. [CrossRef]

15. Hierro-bujalance, C.; Infante-garcia, C.; Marco, A.; Herrera, M.; Carranza-naval, M.J.; Suarez, J.; Alves-martinez, P.; Lubian-lopez, S.; Garcia-alloza, M. Empagliflozin reduces vascular damage and cognitive impairment in a mixed murine model of Alzheimer' $\mathrm{S}$ disease and type 2 diabetes. Alzheimer's Res. Ther. 2020, 4, 1-13.

16. McGill, J.B.; Subramanian, S. Safety of Sodium-Glucose Co-Transporter 2 Inhibitors. Am. J. Cardiol. 2019, 124, S45-S52. [CrossRef] [PubMed]

17. Tahara, A.; Takasu, T.; Yokono, M.; Imamura, M.; Kurosaki, E. Characterization and comparison of sodium-glucose cotransporter 2 inhibitors in pharmacokinetics, pharmacodynamics, and pharmacologic effects. J. Pharmacol. Sci. 2016, 130, 159-169. [CrossRef] [PubMed]

18. Shah, K.; DeSilva, S.; Abbruscato, T. The role of glucose transporters in brain disease: Diabetes and Alzheimer's disease. Int. J. Mol. Sci. 2012, 13, 12629-12655. [CrossRef] [PubMed] 
19. Wright, E.M.; LOO, D.D.F.L.; Hirayama, B.A. Biology of human sodium glucose transporters. Physiol. Rev. 2011, 91, 733-794. [CrossRef] [PubMed]

20. Poppe, R.; Karbach, U.; Gambaryan, S.; Wiesinger, H.; Lutzenburg, M.; Kraemer, M.; Witte, O.W.; Koepsell, H. Expression of the Na+-D-glucose cotransporter SGLT1 in neurons. J. Neurochem. 1997, 69, 84-94. [CrossRef] [PubMed]

21. Koepsell, H. Glucose transporters in brain in health and disease. Pflugers Arch. Eur. J. Physiol. 2020, 472, 1299-1343. [CrossRef] [PubMed]

22. Enerson, B.E.; Drewes, L.R. The rat blood-brain barrier transcriptome. J. Cereb. Blood Flow Metab. 2006, 26, 959-973. [CrossRef]

23. Nguyen, T.; Wen, S.; Gong, M.; Yuan, X.; Xu, D.; Wang, C.; Jin, J.; Zhou, L. Dapagliflozin activates neurons in the central nervous system and regulates cardiovascular activity by inhibiting sglt-2 in mice. Diabetes, Metab. Syndr. Obes. Targets Ther. 2020, 13, 2781-2799. [CrossRef] [PubMed]

24. Gaur, A.; Pal, G.K.; Ananthanarayanan, P.H.; Pal, P. Role of Ventromedial hypothalamus in high fat diet induced obesity in male rats: Association with lipid profile, thyroid profile and insulin resistance. Ann. Neurosci. 2014, 21, 104-107. [CrossRef]

25. Oerter, S.; Förster, C.; Bohnert, M. Validation of sodium/glucose cotransporter proteins in human brain as a potential marker for temporal narrowing of the trauma formation. Int. J. Legal Med. 2019, 133, 1107-1114. [CrossRef] [PubMed]

26. Sebastiani, A.; Greve, F.; Gölz, C.; Förster, C.Y.; Koepsell, H.; Thal, S.C. RS1 (Rsc1A1) deficiency limits cerebral SGLT1 expression and delays brain damage after experimental traumatic brain injury. J. Neurochem. 2018, 147, 190-203. [CrossRef]

27. Malhotra, A.; Kudyar, S.; Gupta, A.; Kudyar, R.; Malhotra, P. Sodium glucose co-transporter inhibitors-A new class of old drugs Int. J. Appl. Basic Med. Res. 2015, 5, 161. [CrossRef] [PubMed]

28. Cinti, F.; Moffa, S.; Impronta, F.; Cefalo, C.M.; Sun, V.A.; Sorice, G.P.; Mezza, T.; Giaccari, A. Spotlight on ertugliflozin and its potential in the treatment of type 2 diabetes: Evidence to date. Drug Des. Devel. Ther. 2017, 11, 2905-2919. [CrossRef] [PubMed]

29. Shakil, S. Molecular Interaction of Anti-Diabetic Drugs with Acetylcholinesterase and Sodium Glucose Co-Transporter 2. J. Cell. Biochem. 2017, 118, 3855-3865. [CrossRef]

30. Shaikh, S.; Rizvi, S.M.; Suhail, T.; Shakil, S.; Abuzenadah, A.; Anis, R.; Naaz, D.; Dallol, A.; Haneef, M.; Ahmad, A.; et al. Prediction of Anti-Diabetic Drugs as Dual Inhibitors Against Acetylcholinesterase and Beta-Secretase: A Neuroinformatics Study. CNS Neurol. Disord.-Drug Targets 2016, 15, 1216-1221. [CrossRef] [PubMed]

31. Lin, B.; Koibuchi, N.; Hasegawa, Y.; Sueta, D.; Toyama, K.; Uekawa, K.; Ma, M.J.; Nakagawa, T.; Kusaka, H.; Kim-Mitsuyama, S. Glycemic control with empagliflozin, a novel selective SGLT2 inhibitor, ameliorates cardiovascular injury and cognitive dysfunction in obese and type 2 diabetic mice. Cardiovasc. Diabetol. 2014, 13, 1-15. [CrossRef] [PubMed]

32. Erdogan, M.A.; Yusuf, D.; Christy, J.; Solmaz, V.; Erdogan, A.; Taskiran, E.; Erbas, O. Highly selective SGLT2 inhibitor dapagliflozin reduces seizure activity in pentylenetetrazol-induced murine model of epilepsy. BMC Neurol. 2018, 18, 1-8. [CrossRef]

33. Akhanli, P.; Hepsen, S.; Emre, A.I.; Duger, H.; Bostan, H.; Kizilgul, M.; Ucan, B.; Cakal, E. AEP816: 24-week impact of dapagliflozin treatment on body weight, body composition, and cardiac risk indicators of patients with type-2 diabetes mellitus. In Endocrine Abstracts; Bioscientifica: Bristol, UK, 2020.

34. Irace, C.; Casciaro, F.; Scavelli, F.B.; Oliverio, R.; Cutruzzolà, A.; Cortese, C.; Gnasso, A. Empagliflozin influences blood viscosity and wall shear stress in subjects with type 2 diabetes mellitus compared with incretin-based therapy. Cardiovasc. Diabetol. 2018, 17, 1-9. [CrossRef] [PubMed]

35. Heerspink, H.J.L.; Perco, P.; Mulder, S.; Leierer, J.; Hansen, M.K.; Heinzel, A.; Mayer, G. Canagliflozin reduces inflammation and fibrosis biomarkers: A potential mechanism of action for beneficial effects of SGLT2 inhibitors in diabetic kidney disease. Diabetologia 2019, 62, 1154-1166. [CrossRef] [PubMed]

36. Xue, L.; Yuan, X.; Zhang, S.; Zhao, X. Investigating the Effects of Dapagliflozin on Cardiac Function, Inflammatory Response, and Cardiovascular Outcome in Patients with STEMI Complicated with T2DM after PCI. Evidence-Based Complement. Altern. Med. 2021, 2021, 9388562. [CrossRef] [PubMed]

37. Ganbaatar, B.; Fukuda, D.; Shinohara, M.; Yagi, S.; Kusunose, K.; Yamada, H.; Soeki, T.; Hirata, K.-i.; Sata, M. Empagliflozin ameliorates endothelial dysfunction and suppresses atherogenesis in diabetic apolipoprotein E-deficient mice. Eur. J. Pharmacol. 2020, 875, 173040. [CrossRef] [PubMed]

38. Liu, H.; Sridhar, V.S.; Lovblom, L.E.; Lytvyn, Y.; Burger, D.; Burns, K.; Brinc, D.; Lawler, P.R.; Cherney, D.Z.I. Markers of Kidney Injury, Inflammation, and Fibrosis Associated with Ertugliflozin in Patients With CKD and Diabetes. Kidney Int. Reports 2021, 6, 2095-2104. [CrossRef] [PubMed]

39. Ye, Y.; Bajaj, M.; Yang, H.C.; Perez-Polo, J.R.; Birnbaum, Y. SGLT-2 Inhibition with Dapagliflozin Reduces the Activation of the Nlrp3/ASC Inflammasome and Attenuates the Development of Diabetic Cardiomyopathy in Mice with Type 2 Diabetes. Further Augmentation of the Effects with Saxagliptin, a DPP4 Inhibitor. Cardiovasc. Drugs Ther. 2017, 31, 119-132. [CrossRef] [PubMed]

40. Kim, S.R.; Lee, S.G.; Kim, S.H.; Kim, J.H.; Choi, E.; Cho, W.; Rim, J.H.; Hwang, I.; Lee, C.J.; Lee, M.; et al. SGLT2 inhibition modulates NLRP3 inflammasome activity via ketones and insulin in diabetes with cardiovascular disease. Nat. Commun. 2020, 11, 1-11. [CrossRef] [PubMed]

41. Lin, F.; Song, C.; Zeng, Y.; Li, Y.; Li, H.; Liu, B.; Dai, M.; Pan, P. Canagliflozin alleviates LPS-induced acute lung injury by modulating alveolar macrophage polarization. Int. Immunopharmacol. 2020, 88. [CrossRef]

42. Lee, S.G.; Lee, S.J.; Lee, J.J.; Kim, J.S.; Lee, O.H.; Kim, C.K.; Kim, D.; Lee, Y.H.; Oh, J.; Park, S.; et al. Anti-inflammatory effect for atherosclerosis progression by sodium-glucose cotransporter 2 (SGLT-2) inhibitor in a normoglycemic rabbit model. Korean Circ. J. 2020, 50, 443-457. [CrossRef] [PubMed] 
43. Xu, L.; Nagata, N.; Chen, G.; Nagashimada, M.; Zhuge, F.; Ni, Y.; Sakai, Y.; Kaneko, S.; Ota, T. Empagliflozin reverses obesity and insulin resistance through fat browning and alternative macrophage activation in mice fed a high-fat diet. BMJ Open Diabetes Res. Care 2019, 7, 1-11. [CrossRef]

44. Bode, D.; Semmler, L.; Wakula, P.; Hegemann, N.; Primessnig, U.; Beindorff, N.; Powell, D.; Dahmen, R.; Ruetten, H.; Oeing, C.; et al. Dual SGLT-1 and SGLT-2 inhibition improves left atrial dysfunction in HFpEF. Cardiovasc. Diabetol. 2021, 20, 1-14. [CrossRef]

45. Hasan, R.; Lasker, S.; Hasan, A.; Zerin, F.; Zamila, M. Canagliflozin ameliorates renal oxidative stress and inflammation by stimulating AMPK-Akt—eNOS pathway in the isoprenaline - induced oxidative stress model. Sci. Rep. 2020, 1-15. [CrossRef] [PubMed]

46. Zaibi, N.; Li, P.; Xu, S.Z. Protective effects of dapagliflozin against oxidative stress-induced cell injury in human proximal tubular cells. PLoS ONE 2021, 16, 1-17. [CrossRef]

47. Iannantuoni, F.; De Marañon, A.M.; Diaz-morales, N.; Falcon, R.; Hernandez-mijares, A.; Rovira-llopis, S. The SGLT2 Inhibitor Empagliflozin Ameliorates the Inflammatory Profile in Type 2 Diabetic Patients and Promotes an Antioxidant Response in Leukocytes. J. Clin. Med. 2019, 8, 1814. [CrossRef]

48. Croteau, D.; Luptak, I.; Chambers, J.M.; Hobai, I.; Panagia, M.; Pimentel, D.R.; Siwik, D.A.; Qin, F.; Colucci, W.S. Effects of sodium-glucose linked transporter 2 inhibition with ertugliflozin on mitochondrial function, energetics, and metabolic gene expression in the presence and absence of diabetes mellitus in mice. J. Am. Heart Assoc. 2021, 10. [CrossRef] [PubMed]

49. Hayden, M.R.; Grant, D.G.; Aroor, A.R.; Demarco, V.G. Empagliflozin Ameliorates Type 2 Diabetes-Induced Ultrastructural Remodeling of the Neurovascular Unit and Neuroglia in the Female db/db Mouse. Brain Sci. 2019, 9, 57. [CrossRef] [PubMed]

50. Bdel-Latif, R.G.; Rifaai, R.A.; Amin, E.F. Empagliflozin alleviates neuronal apoptosis induced by cerebral ischemia/reperfusion injury through HIF-1 $\alpha$ /VEGF signaling pathway. Arch. Pharm. Res. 2020, 43, 514-525. [CrossRef] [PubMed]

51. Zhou, J.; Zhu, J.; Yu, S.; Ma, H.; Chen, J.; Ding, X.; Chen, G.; Liang, Y.; Zhang, Q. Sodium-glucose co-transporter-2 (SGLT-2) inhibition reduces glucose uptake to induce breast cancer cell growth arrest through AMPK/mTOR pathway. Biomed. Pharmacother. 2020, 132, 110821. [CrossRef] [PubMed]

52. Sun, X.; Han, F.; Lu, Q.; Li, X.; Ren, D.; Zhang, J.; Han, Y.; Xiang, Y.K.; Li, J. Empagliflozin Ameliorates Obesity-Related Cardiac Dysfunction by Regulating Sestrin2-Mediated AMPK-mTOR Signaling and Redox Homeostasis in High-Fat Diet-Induced Obese Mice. Diabetes 2020, 69, 1292-1305. [CrossRef] [PubMed]

53. Moellmann, J.; Mann, P.; Krueger, K.; Klinkhammer, B.; Boor, P.; Marx, N.; Lehrke, M. The SGLT2 inhibitor ertugliflozin causes a switch of cardiac substrate utilization leading to reduced cardiac mTOR-signaling, unfolded protein response and apoptosis. Eur. Heart J. 2021, 42, 3289. [CrossRef]

54. Szekeres, Z.; Toth, K.; Szabados, E. The effects of sglt2 inhibitors on lipid metabolism. Metabolites 2021, 11, 87. [CrossRef] [PubMed]

55. Hamed, S.A. Atherosclerosis in epilepsy: Its causes and implications. Epilepsy Behav. 2014, 41, 290-296. [CrossRef]

56. Chiba, Y.; Sugiyama, Y.; Nishi, N.; Nonaka, W.; Murakami, R.; Ueno, M. Sodium/glucose cotransporter 2 is expressed in choroid plexus epithelial cells and ependymal cells in human and mouse brains. Neuropathology 2020, 40, 482-491. [CrossRef]

57. Pearson, A.; Ajoy, R.; Crynen, G.; Reed, J.M.; Algamal, M.; Mullan, M.; Purohit, D.; Crawford, F.; Ojo, J.O. Molecular abnormalities in autopsied brain tissue from the inferior horn of the lateral ventricles of nonagenarians and Alzheimer disease patients. BMC Neurol. 2020, 20, 1-20. [CrossRef] [PubMed]

58. Rizvi, S.; Shakil, S.; Biswas, D.; Shakil, S.; Shaikh, S.; Bagga, P.; Kamal, M. Invokana (Canagliflozin) as a Dual Inhibitor of Acetylcholinesterase and Sodium Glucose Co-Transporter 2: Advancement in Alzheimer's Disease- Diabetes Type 2 Linkage via an Enzoinformatics Study. CNS Neurol. Disord.—Drug Targets 2014, 13, 447-451. [CrossRef]

59. Behnammanesh, G.; Durante, Z.E.; Peyton, K.J.; Martinez-Lemus, L.A.; Brown, S.M.; Bender, S.B.; Durante, W. Canagliflozin inhibits human endothelial cell proliferation and tube formation. Front. Pharmacol. 2019, 10. [CrossRef] [PubMed]

60. Shaikh, S.; Rizvi, S.M.D.; Shakil, S.; Riyaz, S.; Biswas, D.; Jahan, R. Forxiga (dapagliflozin): Plausible role in the treatment of diabetes-associated neurological disorders. Biotechnol. Appl. Biochem. 2016, 63, 145-150. [CrossRef]

61. Ferreira-Vieira, H.T.; Guimaraes, M.I.; Silva, R.F.; Ribeiro, F.M. Alzheimer's disease: Targeting the Cholinergic System. Curr. Neuropharmacol. 2016, 14, 101-115. [CrossRef]

62. Arafa, N.M.S.; Ali, E.H.A.; Hassan, M.K. Canagliflozin prevents scopolamine-induced memory impairment in rats: Comparison with galantamine hydrobromide action. Chem. Biol. Interact. 2017, 277, 195-203. [CrossRef] [PubMed]

63. Bathina, S.; Das, U.N. Brain-derived neurotrophic factor and its clinical Implications. Arch. Med. Sci. 2015, 11, 1164-1178. [CrossRef] [PubMed]

64. Zhen, Y.F.; Zhang, J.; Liu, X.Y.; Fang, H.; Tian, L.B.; Zhou, D.H.; Kosten, T.R.; Zhang, X.Y. Low BDNF is associated with cognitive deficits in patients with type 2 diabetes. Psychopharmacology 2013, 227, 93-100. [CrossRef] [PubMed]

65. Bi, C.; Fu, Y.; Li, B. Brain-derived neurotrophic factor alleviates diabetes mellitus-accelerated atherosclerosis by promoting M2 polarization of macrophages through repressing the STAT3 pathway. Cell. Signal. 2020, 70, 109569. [CrossRef] [PubMed]

66. Bos, D.; Vernooij, M.W.; De Bruijn, R.F.A.G.; Koudstaal, P.J.; Hofman, A.; Franco, O.H.; Van Der Lugt, A.; Ikram, M.A. Atherosclerotic calcification is related to a higher risk of dementia and cognitive decline. Alzheimer's Dement. 2015, 11, 639-647.e1. [CrossRef] [PubMed] 
67. Wingo, A.P.; Fan, W.; Duong, D.M.; Gerasimov, E.S.; Dammer, E.B.; Liu, Y.; Harerimana, N.V.; White, B.; Thambisetty, M.; Troncoso, J.C.; et al. Shared proteomic effects of cerebral atherosclerosis and Alzheimer's disease on the human brain. Nat. Neurosci. 2020, 23, 696-700. [CrossRef]

68. Sabia, S.; Fayosse, A.; Dumurgier, J.; Schnitzler, A.; Empana, J.P.; Ebmeier, K.P.; Dugravot, A.; Kivimäki, M.; Singh-Manoux, A. Association of ideal cardiovascular health at age 50 with incidence of dementia: 25 Year follow-up of Whitehall II cohort study. BMJ 2019, 366, 1-10. [CrossRef] [PubMed]

69. Liu, Z.; Ma, X.; Ilyas, I.; Zheng, X.; Luo, S.; Little, P.J.; Kamato, D.; Sahebkar, A.; Wu, W.; Weng, J.; et al. Impact of sodium glucose cotransporter 2 (SGLT2) inhibitors on atherosclerosis: From pharmacology to pre-clinical and clinical therapeutics. Theranostics 2021, 11, 4502-4515. [CrossRef] [PubMed]

70. O'Leary, D.H.; Polak, J.F.; Kronmal, R.A.; Manolio, T.A.; Burke, G.L.; Wolfson, S.K. Carotid-Artery Intima and Media Thickness as a Risk Factor for Myocardial Infarction and Stroke in Older Adults. N. Engl. J. Med. 1999, 340, 14-22. [CrossRef]

71. Feinkohl, I.; Keller, M.; Robertson, C.M.; Morling, J.R.; Williamson, R.M.; Nee, L.D.; McLachlan, S.; Sattar, N.; Welsh, P.; Reynolds, R.M.; et al. Clinical and subclinical macrovascular disease as predictors of cognitive decline in older patients with type 2 diabetes: The Edinburgh type 2 diabetes study. Diabetes Care 2013, 36, 2779-2786. [CrossRef]

72. Suridjan, I.; Pollock, B.G.; Verhoeff, N.P.L.G.; Voineskos, A.N.; Chow, T.; Rusjan, P.M.; Lobaugh, N.J.; Houle, S.; Mulsant, B.H.; Mizrahi, R. In-vivo imaging of grey and white matter neuroinflammation in Alzheimer's disease: A positron emission tomography study with a novel radioligand, "18 F"-FEPPA. Mol. Psychiatry 2015, 20, 1579-1587. [CrossRef] [PubMed]

73. Walker, K.A.; Ficek, B.N.; Westbrook, R. Understanding the Role of Systemic Inflammation in Alzheimer's Disease. ACS Chem. Neurosci. 2019, 10, 3340-3342. [CrossRef] [PubMed]

74. Walker, K.A.; Gottesman, R.F.; Wu, A.; Knopman, D.S.; Gross, A.L.; Mosley, T.H.; Selvin, E.; Windham, B.G. Systemic inflammation during midlife and cognitive change over 20 years: The ARIC Study. Neurology 2019, 92, E1256-E1267. [CrossRef] [PubMed]

75. Rochfort, K.D.; Cummins, P.M. The blood-brain barrier endothelium: A target for pro-inflammatory cytokines. Biochem. Soc. Trans. 2015, 43, 702-706. [CrossRef] [PubMed]

76. Vogels, T.; Murgoci, A.N.; Hromádka, T. Intersection of pathological tau and microglia at the synapse. Acta Neuropathol. Commun. 2019, 7, 109. [CrossRef]

77. Wang, W.Y.; Tan, M.S.; Yu, J.T.; Tan, L. Role of pro-inflammatory cytokines released from microglia in Alzheimer's disease. Ann. Transl. Med. 2015, 3, 1-15. [CrossRef]

78. Ridker, P.M.; Everett, B.M.; Thuren, T.; MacFadyen, J.G.; Chang, W.H.; Ballantyne, C.; Fonseca, F.; Nicolau, J.; Koenig, W.; Anker, S.D.; et al. Antiinflammatory Therapy with Canakinumab for Atherosclerotic Disease. N. Engl. J. Med. 2017, 377, 1119-1131. [CrossRef] [PubMed]

79. Rooks, M. G and Garrett, W.S, 2016 The Role of Cytokines in the Development of Atherosclerosis. Biochemistry 2016, 176, 1358-1370. [CrossRef]

80. Kelley, N.; Jeltema, D.; Duan, Y.; He, Y. The NLRP3 Inflammasome: An Overview of Mechanisms of Activation and Regulation. Int. J. Mol. Sci. 2019, 20, 3328. [CrossRef] [PubMed]

81. Jin, Y.; Fu, J. Novel Insights into the NLRP3 Inflammasome in Atherosclerosis. J. Am. Heart Assoc. 2019, 8, 1-12. [CrossRef]

82. Van Der Heijden, T.; Kritikou, E.; Venema, W.; Van Duijn, J.; Van Santbrink, P.J.; Slütter, B.; Foks, A.C.; Bot, I.; Kuiper, J. NLRP3 Inflammasome Inhibition by MCC950 Reduces Atherosclerotic Lesion Development in Apolipoprotein E-Deficient Mice-Brief Report. Arterioscler. Thromb. Vasc. Biol. 2017, 37, 1457-1461. [CrossRef] [PubMed]

83. Tejera, D.; Mercan, D.; Sanchez-caro, J.M.; Hanan, M.; Greenberg, D.; Soreq, H.; Latz, E.; Golenbock, D.; Heneka, M.T. Systemic inflammation impairs microglial A b clearance through NLRP 3 inflammasome. EMBO J. 2019, 38, e101064. [CrossRef] [PubMed]

84. Lonnemann, N.; Hosseini, S.; Marchetti, C.; Skouras, D.B.; Stefanoni, D.; D’Alessandro, A.; Dinarello, C.A.; Korte, M. The NLRP3 inflammasome inhibitor OLT1177 rescues cognitive impairment in a mouse model of Alzheimer's disease. Proc. Natl. Acad. Sci. USA 2020, 117, 32145-32154. [CrossRef] [PubMed]

85. Lathe, R.; Sapronova, A.; Kotelevtsev, Y. Atherosclerosis and Alzheimer-Diseases with a common cause? Inflammation, oxysterols, vasculature. BMC Geriatr. 2014, 14, 1-30. [CrossRef]

86. Barrett, T.J. Macrophages in Atherosclerosis Regression. Arterioscler. Thromb. Vasc. Biol. 2020, 40, 20-33. [CrossRef] [PubMed]

87. Zhang, Z.; Li, X.G.; Wang, Z.H.; Song, M.; Yu, S.P.; Kang, S.S.; Liu, X.; Zhang, Z.; Xie, M.; Liu, G.P.; et al. $\delta$-Secretase-cleaved Tau stimulates A $\beta$ production via upregulating STAT1-BACE1 signaling in Alzheimer's disease. Mol. Psychiatry 2021, 26, 586-603. [CrossRef]

88. Li, X.; Hong, X.; Wang, Y.; Zhang, S.; Zhang, J.; Li, X.; Liu, Y.; Sun, D.; Feng, Q.; Ye, J.; et al. Tau accumulation triggers STAT 1-dependent memory deficits by suppressing NMDA receptor expression. EMBO Rep. 2019, 20, 1-18. [CrossRef]

89. Lee, N.; Heo, Y.J.; Choi, S.E.; Jeon, J.Y.; Han, S.J.; Kim, D.J.; Kang, Y.; Lee, K.W.; Kim, H.J. Anti-inflammatory Effects of Empagliflozin and Gemigliptin on LPS-Stimulated Macrophage via the IKK/NF- K B, MKK7/JNK, and JAK2/STAT1 Signalling Pathways. J. Immunol. Res. 2021, 2021. [CrossRef] [PubMed]

90. Faraco, G.; Sugiyama, Y.; Lane, D.; Garcia-Bonilla, L.; Chang, H.; Santisteban, M.M.; Racchumi, G.; Murphy, M.; Van Rooijen, N.; Anrather, J.; et al. Perivascular macrophages mediate the neurovascular and cognitive dysfunction associated with hypertension. J. Clin. Invest. 2016, 126, 4674-4689. [CrossRef] [PubMed]

91. He, H.; Mack, J.J.; Güç, E.; Warren, C.M.; Squadrito, M.L.; Kilarski, W.W.; Baer, C.; Freshman, R.D.; McDonald, A.I.; Ziyad, S.; et al. Perivascular Macrophages Limit Permeability. Arterioscler. Thromb. Vasc. Biol. 2016, 36, 2203-2212. [CrossRef] [PubMed] 
92. Kerkhofs, D.; Van Hagen, B.T.; Milanova, I.V.; Schell, K.J.; Van Essen, H.; Wijnands, E.; Goossens, P.; Blankesteijn, W.M.; Unger, T.; Prickaerts, J.; et al. Pharmacological depletion of microglia and perivascular macrophages prevents Vascular Cognitive Impairment in Ang II-induced hypertension. Theranostics 2020, 10, 9512-9527. [CrossRef]

93. Mittal, M.; Siddiqui, M.R.; Tran, K.; Reddy, S.P.; Malik, A.B. Reactive Oxygen Species in Inflammation and Tissue Injury. Antioxid. Redox Signal. 2014, 20, 1126-1167. [CrossRef] [PubMed]

94. Zalba, G. Oxidative Stress in Vascular Pathophysiology: Still Much to Learn. Antioxidants 2021, 10, 673. [CrossRef] [PubMed]

95. Huang, W.E.N.J.; Zhang, X.I.A.; Chen, W.E.I.W.E.I. Role of oxidative stress in Alzheimer's disease (Review). Biomed. Rep. 2016, 4, 519-522. [CrossRef]

96. Hajjar, I.; Hayek, S.S.; Goldstein, F.C.; Martin, G.; Jones, D.P.; Quyyumi, A. Oxidative stress predicts cognitive decline with aging in healthy adults: An observational study. J. neuroinflammation 2018, 15, 1-7. [CrossRef] [PubMed]

97. Yaribeygi, H.; Atkin, S.L.; Butler, A.E. Sodium—Glucose cotransporter inhibitors and oxidative stress: An update. J. Cell. Physiol. 2019, 234, 3231-3237. [CrossRef] [PubMed]

98. Cenini, G.; Voos, W. Mitochondria as potential targets in Alzheimer disease therapy: An update. Front. Pharmacol. 2019, 10, 1-20. [CrossRef]

99. Khacho, M.; Clark, A.; Svoboda, D.S.; MacLaurin, J.G.; Lagace, D.C.; Park, D.S.; Slack, R.S. Mitochondrial dysfunction underlies cognitive defects as a result of neural stem cell depletion and impaired neurogenesis. Hum. Mol. Genet. 2017, 26, 3327-3341. [CrossRef] [PubMed]

100. Sa-nguanmoo, P.; Tanajak, P.; Kerdphoo, S.; Jaiwongkam, T.; Pratchayasakul, W.; Chattipakorn, N.; Chattipakorn, S.C. SGLT2inhibitor and DPP-4 inhibitor improve brain function via attenuating mitochondrial dysfunction, insulin resistance, inflammation, and apoptosis in HFD-induced obese rats. Toxicol. Appl. Pharmacol. 2017, 333, 43-50. [CrossRef] [PubMed]

101. Mao, Z.; Zhang, W. Role of mTOR in Glucose and Lipid Metabolism. Int. J. Mol. Sci. 2018, 19, 2043. [CrossRef] [PubMed]

102. Uddin, S.; Bin-jumah, M.N. Multifarious roles of mTOR signaling in cognitive aging and cerebrovascular dysfunction of Alzheimer' s disease. Iubmb Life 2020, 72, 1843-1855. [CrossRef] [PubMed]

103. Van Skike, C.E.; Galvan, V. A Perfect sTORm: The Role of the Mammalian Target of Rapamycin ( mTOR ) in Cerebrovascular Dysfunction of Alzheimer's Disease: A Mini-Review. Gerontology 2018, 64, 205-211. [CrossRef]

104. Esterline, R.; Oscarsson, J.; Burns, J. International Review of Neurobiology, 1st ed.; Elsevier Inc.: Amsterdam, The Netherlands, 2020; pp. 113-140.

105. Stanciu, G.D.; Rusu, R.N.; Bild, V.; Filipiuc, L.E.; Tamba, B.I.; Ababei, D.C. Systemic actions of sglt2 inhibition on chronic mtor activation as a shared pathogenic mechanism between alzheimer's disease and diabetes. Biomedicines 2021, 9, 576. [CrossRef] [PubMed]

106. Packer, M. SGLT2 inhibitors produce cardiorenal benefits by promoting adaptive cellular reprogramming to induce a state of fasting mimicry: A paradigm shift in understanding their mechanism of action. Diabetes Care 2020, 43, 508-511. [CrossRef] [PubMed]

107. Al Hamed, F.A.; Elewa, H. Potential Therapeutic Effects of Sodium Glucose-linked Cotransporter 2 Inhibitors in Stroke. Clin. Ther. 2020, 42, e242-e249. [CrossRef]

108. Yan, C.; Zhou, Y.; Chen, Q.; Luo, Y.; Zhang, J.H.; Huang, H.; Shao, A. Dysfunction of the neurovascular unit in diabetes-related neurodegeneration. Biomed. Pharmacother. 2020, 131, 110656. [CrossRef]

109. Shabir, O.; Berwick, J.; Francis, S.E. Neurovascular dysfunction in vascular dementia, Alzheimer's and atherosclerosis. BMC Neurosci. 2018, 19, 1-16. [CrossRef]

110. Liu, J.; Zhu, Y.; Wu, Y.; Liu, Y.; Teng, Z.; Hao, Y. Association of carotid atherosclerosis and recurrent cerebral infarction in the Chinese population: A meta-analysis. Neuropsychiatr Dis Treat. 2017, 13, 527-533. [CrossRef]

111. Sun, J.; Tan, L.; Yu, J. Post-stroke cognitive impairment: Epidemiology, mechanisms and management. Ann. Transl. Med. 2014, 2. [CrossRef]

112. Usman, M.S.; Siddiqi, T.J.; Memon, M.M.; Khan, M.S.; Rawasia, W.F.; Talha Ayub, M.; Sreenivasan, J.; Golzar, Y. Sodium-glucose co-transporter 2 inhibitors and cardiovascular outcomes: A systematic review and meta-analysis. Eur. J. Prev. Cardiol. 2018, 25, 495-502. [CrossRef] [PubMed]

113. Wajngarten, M.; Sampaio Silva, G. Hypertension and stroke: Update on treatment. Eur. Cardiol. Rev. 2019, 14, 111-115. [CrossRef] [PubMed]

114. Briasoulis, A.; Al Dhaybi, O.; Bakris, G.L. SGLT2 Inhibitors and Mechanisms of Hypertension. Curr. Cardiol. Rep. 2018, 20, 8-10. [CrossRef] [PubMed]

115. Ishida, N.; Saito, M.; Sato, S.; Koepsell, H.; Taira, E.; Hirose, M. SGLT1 participates in the development of vascular cognitive impairment in a mouse model of small vessel disease. Neurosci. Lett. 2020, 727, 134929. [CrossRef] [PubMed]

116. Yamazaki, Y.; Harada, S.; Wada, T.; Hagiwara, T.; Yoshida, S.; Tokuyama, S. Sodium influx through cerebral sodium-glucose transporter type 1 exacerbates the development of cerebral ischemic neuronal damage. Eur. J. Pharmacol. 2017. [CrossRef] [PubMed]

117. Sim, A.Y.; Barua, S.; Kim, J.Y.; Lee, Y.H.; Lee, J.E. Role of DPP-4 and SGLT2 Inhibitors Connected to Alzheimer Disease in Type 2 Diabetes Mellitus. Front. Neurosci. 2021, 15, 1-11. [CrossRef] 
118. Langbaum, J.B.S.; Chen, K.; Lee, W.; Reschke, C.; Bandy, D.; Fleisher, A.S.; Alexander, G.E.; Foster, N.L.; Weiner, M.W.; Koeppe, R.A.; et al. Categorical and correlational analyses of baseline fluorodeoxyglucose positron emission tomography images from the Alzheimer's Disease Neuroimaging Initiative (ADNI). Neuroimage 2009, 45, 1107-1116. [CrossRef] [PubMed]

119. Anthony, K.; Reed, L.J.; Dunn, J.T.; Bingham, E.; Hopkins, D.; Marsden, P.K.; Amiel, S.A. The Cerebral Basis for Impaired Control of Food Intake in. Diabetes 2006, 55, 2986-2992. [CrossRef]

120. Hernandez, F.; Lucas, J.J.; Avila, J. GSK3 and tau: Two convergence points in Alzheimer's disease. J. Alzheimer's Dis. 2013, 33, 141-144. [CrossRef]

121. Inaba, Y.; Hashiuchi, E.; Watanabe, H.; Kimura, K.; Sato, M.; Kobayashi, M.; Matsumoto, M.; Kitamura, T.; Kasuga, M.; Inoue, H. Hepatic Gluconeogenic Response to Single and Long-Term SGLT2 Inhibition in Lean/Obese Male Hepatic G6pc-Reporter Mice. Endocrinology 2019, 160, 2811-2824. [CrossRef] 